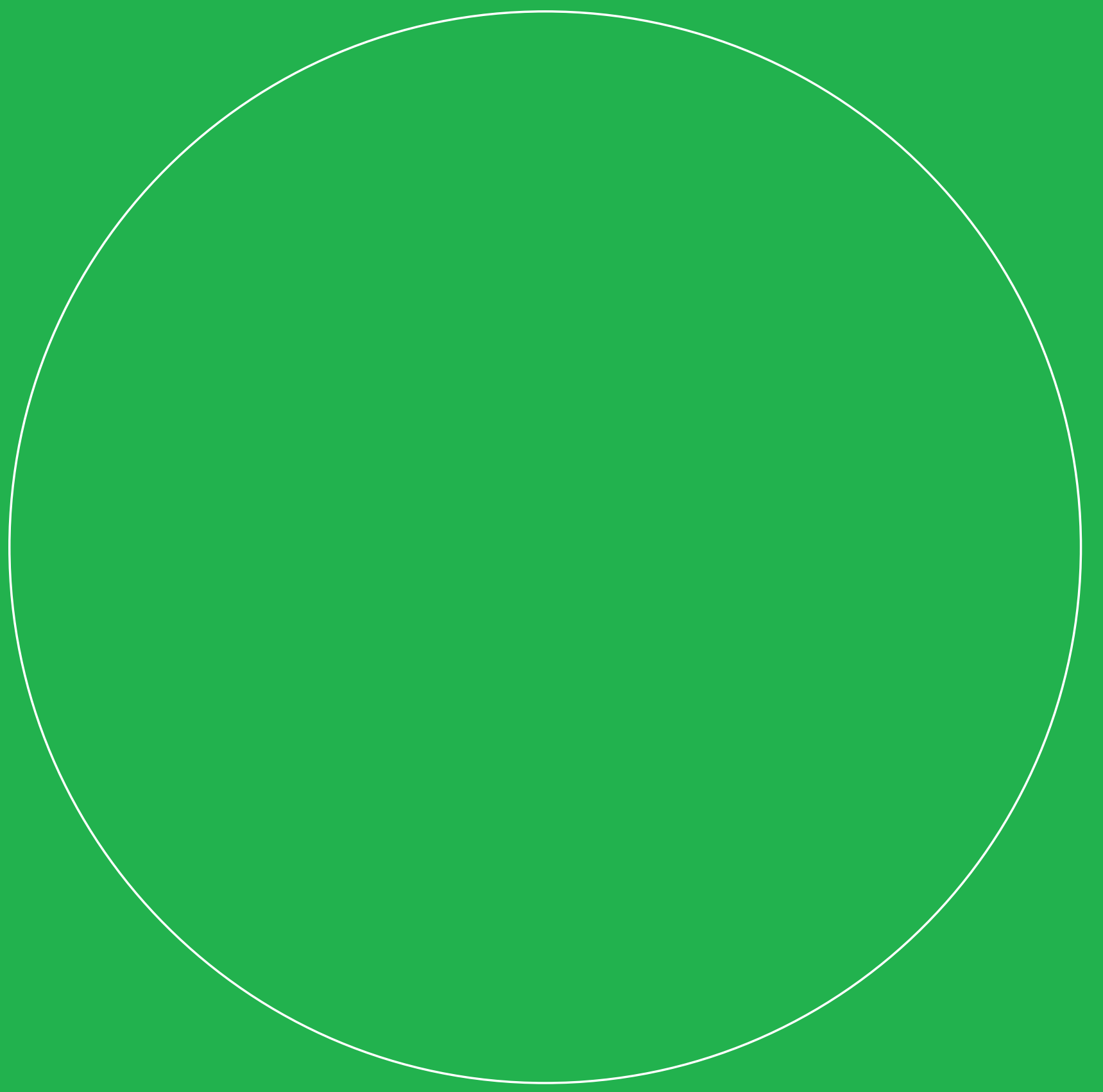

\title{
Naar een Nederlands Food Integrity Net (NL-FINE)
}

G. (Görkem) Simsek-Senel PhD, prof.dr.ir. J.L. (Jan) Top, prof.dr.ir. S.M. (Saskia) van Ruth, dr. L.A. (Lorijn) van Rooijen, S. (Seth) Tromp MSc BA 



\title{
Naar een Nederlands Food Integrity Net (NL-FINE)
}

\author{
Auteurs: $\quad$ G. (Görkem) Simsek-Senel PhD, prof.dr.ir. J.L. (Jan) Top, prof.dr.ir. S.M. (Saskia) van Ruth, \\ dr. L.A. (Lorijn) van Rooijen, S. (Seth) Tromp MSc BA
}

Instituut: Wageningen Food \& Biobased Research (WFBR) \& Wageningen Food Safety Research (WFSR)

Dit onderzoek is uitgevoerd door Wageningen Food \& Biobased Research in opdracht van en gefinancierd door Ministerie van Landbouw, natuur en voedselkwaliteit, in het kader van MIP Trusted Source (projectnummer BO-43-002.01-006).

Wageningen Food \& Biobased Research

Wageningen, december 2020

Vertrouwelijk tot 15 januari 2021

Rapport: 2112 
Versie: definitief

Vertrouwelijk tot en met: 15 januari 2021

Reviewer: dr. R.J. (Rutger) Vlek

Goedgekeurd door: dr.ir. H. (Henk) Wensink

Opdrachtgever: Ministerie van Landbouw, natuur en voedselkwaliteit

Financier: Ministerie van Landbouw, natuur en voedselkwaliteit

Intern project: 6234169300 NL Food Integrity

Wageningen Food \& Biobased Research heeft haar onderzoek onafhankelijk en integer verricht.

Dit rapport is onder embargo tot 15 januari 2021. Daarna is dit rapport gratis te downloaden op https://doi.org/10.18174/538347/ of op www.wur.nl/wfbr (onder publicaties).

(C) 2020 Wageningen Food \& Biobased Research, instituut binnen de rechtspersoon Stichting Wageningen Research.

Vertrouwelijk rapport. Uit deze uitgave mag niets worden gereproduceerd en/of openbaar gemaakt zonder voorafgaande schriftelijke toestemming van de directeur van Wageningen Food \& Biobased Research.

Postbus 17, 6700 AA Wageningen, T 03174800 84, E info.wfbr@wur.nl, www.wur.nl/wfbr. Wageningen Food \& Biobased Research is onderdeel van Wageningen University \& Research.

Alle rechten voorbehouden. Niets uit deze uitgave mag worden verveelvoudigd, opgeslagen in een geautomatiseerd gegevensbestand of openbaar gemaakt in enige vorm of op enige wijze, hetzij elektronisch, hetzij mechanisch, door fotokopieën, opnamen of enige andere manier, zonder voorafgaande schriftelijke toestemming van de uitgever. De uitgever aanvaardt geen aansprakelijkheid voor eventuele fouten of onvolkomenheden. 


\section{Inhoud}

$\begin{array}{ll}\text { Samenvatting } & 4\end{array}$

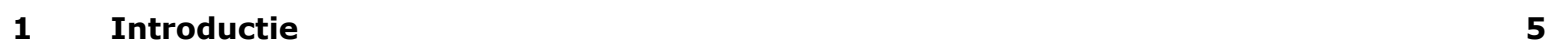

$2 \quad$ Draagvlak in de Nederlandse voedingssector $\quad 6$

$3 \quad$ Bestaande oplossingen $\quad 7$

$\begin{array}{lll}3.1 & \text { Bestaande databases } & 7\end{array}$

3.2 Uniform datamodel uit literatuur $\quad 8$

3.3 Food Industry Intelligence Network (FIIN) 8

$\begin{array}{llr}4 & \text { Eisen en datamodel } & 10\end{array}$

$\begin{array}{lll}4.1 & \text { Definities van voedselfraude } & 10\end{array}$

4.2 Randvoorwaarden en eisen aan de database $\quad 11$

4.3 Database: data velden en het aanleveren van data $\quad 12$

4.4 Voorgesteld gegevensmodel 12

5 Conclusies en vervolg $\quad 14$

$\begin{array}{ll}\text { Literatuur } & 15\end{array}$ 


\section{Samenvatting}

Bij de productie van en handel in levensmiddelen is er regelmatig sprake van fraude. Dit is in strijd met de wet, resulteert in economische schade, en kan leiden tot voedselveiligheidsrisico's. Er is daarom steeds meer aandacht voor het beheersen van fraude. Een van de manieren om beter met fraude om te gaan is door informatie over incidenten en risico-indicaties rond frauduleuze productie te delen. Als fraude-informatie per product of productcategorie beschikbaar is, kunnen afnemers gericht maatregelen nemen.

Dit onderzoek richt zich op de mogelijke behoefte aan een voedselintegriteitsnetwerk in Nederland, een platform voor het delen van informatie over voedselfraudegevallen. We hebben daarvoor gekeken naar bestaande oplossingen in het buitenland en naar draagvlak in Nederland.

In eerste instantie zijn drie grote retailorganisaties gepeild. Meer informatie over mogelijke fraudeincidenten kan helpen bij het maken van betere interne risicoanalyses voor verschillende voedselproducten en productgroepen. Retailers zijn geïnteresseerd als het platform iets toevoegt aan de bestaande informele onderlinge communicatie. Verder stelt men als voorwaarde dat er brede deelname is vanuit de keten, dat die deelname anoniem is en dat alleen bedrijven meedoen. CBL heeft al eerder belangstelling getoond en FNLI bespreekt het voorstel met haar deelnemers.

Het Britse initiatief FIIN kan dienen als voorbeeld voor NL-FINE. Zij stellen echter geen data ter beschikking, alleen trendanalyses. Verder neemt FIIN alleen fraude op basis van lab testresultaten op. Beide aannames zijn waarschijnlijk niet van toepassing voor NL-FINE.

In dit rapport hebben we verdere een eenvoudig datamodel voor het potentiële netwerk voorgesteld op basis van een aantal bestaande databases en een eerder opgesteld uniform model.

Voor het vervolg zouden in 2021 de volgende activiteiten uitgevoerd kunnen worden.

- $\quad$ Andere partijen in de keten polsen

- Een stuurgroep inrichten om de belangen van de verschillende partijen te vertegenwoordigen

- Gedetailleerd plan van eisen en ontwerp database opstellen

- $\quad$ Systeemontwikkeling en test

- Beperkte gebruikstest en evaluatie

De volgende stap is om een gedetailleerd projectvoorstel met concrete vervolgacties voor te leggen aan het Ministerie van LNV. 


\section{$1 \quad$ Introductie}

Bij de productie van levensmiddelen is er regelmatig sprake van fraude. Dit is in strijd met de wet, resulteert in economische schade, en kan leiden tot voedselveiligheidsrisico's. Meer in het algemeen schaadt fraude het vertrouwen van consumenten in de voedselsector, terwijl slechts een deel van de fabrikanten in die sector fraudeert en fabrikanten zelf ook het slachtoffer kunnen zijn van frauderende leveranciers. Er is daarom steeds meer aandacht voor het beheersen van fraude. Door het uitvoeren van kwetsbaarheidsanalyses en door verbeterde fraudedetectie kunnen fabrikanten en retailers zelf de integriteit, veiligheid en kwaliteit van hun voedselproducten waarborgen. Daarmee kunnen ze verantwoordelijkheid tonen, en boetes of kosten vanwege fraude door hun leveranciers voorkomen.

Een van de manieren om beter met fraude om te gaan is door informatie over incidenten en risicoindicaties rond frauduleuze productie te delen. Als fraude-informatie per product of productcategorie beschikbaar is, kunnen afnemers gerichter handelen, maar ook met minder kwaliteitscontroles meer fraude detecteren. Een uitdaging hierbij is dat bedrijven specifieke details rond fraude bij voorkeur niet zonder meer delen vanwege de kans op misverstanden en imagoschade. Daarom is er een zekere mate van anonimiseren en abstractie nodig.

Het beter delen van productdata door de voedselketen heen wordt al onderzocht in het MIP-project Trusted Source ${ }^{1}$. In vier pilots worden informatiestromen in voedselketens onderzocht, wat o.a. resulteert in antwoorden op vragen rond beschikbaarheid van data, het gebruik van standaarden en de betekenis hiervan voor de consument. In alle gevallen gaat het om het delen van informatie over voedselproducten, van ingrediënten tot $\mathrm{CO}_{2}$-footprint. Het delen van fraude-informatie in voedselketens gaat over een aanvullend aspect: hoe staat het met de integriteit van voedselproducten? Met andere woorden, is dit product wat men claimt dat het is?

Het doel van dit rapport is om de resultaten te presenteren van ons onderzoek naar de behoefte aan een voedselintegriteitsnetwerk in Nederland, een platform voor het delen van informatie over voedselfraudegevallen. We hebben daarvoor gekeken naar een bestaande oplossing in het buitenland en naar draagvlak in Nederland. De opzet van dit rapport is als volgt. In Hoofdstuk 2 presenteren we de uitkomst van gesprekken met Nederlandse retailers. Hoofdstuk 3 geeft een overzicht van bestaande databases en een Brits initiatief voor een voedselintegriteitsnetwerk. De vereisten voor een toekomstig netwerk worden gepresenteerd in Hoofdstuk 4. In de conclusie (Hoofdstuk 5) doen we suggesties over hoe verder te gaan naar een mogelijk Nederlands Food Integrity Net.

\footnotetext{
${ }^{1}$ Zie www.trustedsource.nl
} 


\section{Draagvlak in de Nederlandse voedingssector}

Om te onderzoeken of er binnen de Nederlandse voedselsector behoefte bestaat aan het delen van informatie over incidenten van voedselfraude, zijn er verschillende gesprekken geweest tussen leden van het projectteam en actoren uit de voedselsector. In eerste instantie hebben we ons hierbij op drie grote retailers in Nederland gericht, omdat daar de impact van fraude samenkomt en het de consument kan raken.

In principe bestaat er bij de afgevaardigden van de retailers die we hebben gesproken belangstelling voor een database met gegevens over voedselfraude incidenten. In de huidige situatie houden de verantwoordelijken voor productintegriteit bij de verschillende retailers elkaar meestal op de hoogte. Als een van hen onregelmatigheden waarneemt bij een bepaald product of een bepaalde producent neemt men contact op met andere retailers op wie dit ook een effect kan hebben. Deze informatieuitwisseling is niet gestructureerd en afhankelijk van de onderlinge connecties. Overigens leiden, volgens de retailers, fraudegevallen in de praktijk niet vaak tot terugroepacties.

Incidenten die een paar stappen eerder in de keten voorkomen zijn mogelijk minder zichtbaar voor de retailers, aangezien deze wellicht niet via onderlinge connecties worden gecommuniceerd. Een database die data van verschillende ketenpartijen krijgt aangeleverd kan hier meer inzicht in geven. De verantwoordelijken voor productintegriteit bij de retailers die wij gesproken hebben, gaven aan dat meer informatie over (trends in) fraude-incidenten kan helpen bij het maken van betere interne risicoanalyses voor verschillende voedselproduct(groep)en.

Uit onze gesprekken met afgevaardigden van de retailers kwam onder meer naar voren dat een voedselfraude-informatienetwerk voor hun van meer waarde zou zijn als ook andere ketenpartijen hieraan deel zouden nemen. Naast het feit dat dit voor een completer beeld van de incidenten zal zorgen, wordt zo ook voorkomen dat de retailers een waakhondfunctie krijgen. Om deze reden hebben we vervolgens contact gezocht met overkoepelende organisaties als CBL en FNLI, met partijen uit de cateringsector en met het Gilde van Meesterkoks. CBL geeft al langer aan een dergelijk initiatief nuttig te vinden en FNLI zal dit bespreken met hun vertegenwoordigers van voedselproducenten. Zowel de retailers als de bovengenoemde koepelorganisaties gaven aan dat er in principe behoefte is aan een integriteitsnetwerk voor het delen van gegevens, mits het iets toevoegt aan de huidige informele incidentcommunicatie. 


\section{Bestaande oplossingen}

Deze sectie behandelt bestaande databases voor het delen van informatie over voedselfraude en de daarin gebruikte datamodellen. De onderzochte oplossingen zijn:

- $\quad$ Food Fraud Database (US)

- $\quad$ Food Shield Database (US)

- $\quad$ Rapid Alert System for Food and Feed (RASFF, EU)

Deze systemen worden hieronder kort toegelicht in paragraaf 3.1. Een uitgebreid overzicht van bestaande oplossingen is te vinden in een rapport van Wageningen Food Safety Research ${ }^{1}$. In paragraaf 3.2 presenteren we een uniform datamodel voor het representeren van fraude-informatie. In paragraaf 3.3 leggen we uit wat het Food Industry Intelligence Network (FIIN, UK) doet. FIIN is niet zozeer een database, maar een Brits voedselintegriteitsnetwerk dat fraude-incidenten van hun leden verzamelt en de verzamelde informatie in rapportformaat met hen deelt.

\subsection{Bestaande databases}

\section{Food Fraud Database (US)}

De Food Fraud Database signaleert fraudegevoelige ingrediënten door de uitkomsten van de bijbehorende analytische detectiemethodes vast te leggen. De inhoud van deze database is dus representatief voor geanalyseerde producten. Er worden hiervoor data verzameld uit o.a. wetenschappelijke publicaties, mediaberichten en gerechtelijke dossiers. De Food Fraud Database is enige tijd geleden overgegaan van de United States Pharmacopeial Convention (USP) naar Decernis, en daarmee niet meer publiek toegankelijk. Op basis van de literatuur is bekend dat de volgende databasevelden in elk geval deel uitmaken van het onderliggende datamodel:

- Type rapportage (wetenschappelijk, media, anders)

- Ingrediëntcategorie

- Type fraude

- Contaminant(en)

Het datamodel van de Food Fraud Database bevat geen locatiegegevens.

\section{Food Shield Database (US)}

De Food Shield Database omvat fraude incidenten uit mediaberichten. Op basis van de literatuur is bekend dat de volgende databasevelden in elk geval deel uitmaken van het onderliggende datamodel:

- $\quad$ Productcategorie

- Tijdsperiode

- (Groep) veroorzakers (bijv. 'China')

- Locatie

\section{Rapid Alert System for Food and Feed (RASFF)}

Het Rapid Alert System for Food and Feed (RASFF) is beperkt tot voedselfraude-incidenten die de voedselveiligheid beïnvloeden, en die bovendien een internationaal karakter hebben. RASFF is bedoeld om een 24/7 early warning system te zijn voor binnen de EU. Het idee is om een incident te kunnen herleiden tot de bron, en zodoende de getroffen producten uit de handel te kunnen nemen. RASFF is publiek toegankelijk, en op basis van een bezoek aan dit systeem is op te maken dat het datamodel de volgende velden bevat:

- Classificatie van de melding ('alert/border rejection/information for attention/information for follow up/upgraded')

- $\quad$ Datum van de melding

- Referentie (unieke aanduiding)

- Land van waaruit de melding is gekomen 
- Onderwerp van de melding (deze beschrijving bevat o.a. de contaminant, het product en het gerelateerde land)

- Productcategorie

- Type ('food/feed/contact material')

- Inschatting van het risico ('serious/not serious/undecided')

- Details

Het RASFF-detailscherm geeft extra informatie over de achtergrond van de melding, zoals:

- Wat de basis van de melding is ('border control/official control on the market/company own check/consumer compliant/food poisoning')

- Welke actie er ondernomen is

- Wat er bekend is over de verspreiding van het product

\subsection{Uniform datamodel uit literatur}

Ten slotte is er in de literatuur een uniform datamodel voorgesteld ${ }^{1}$ op basis van de Food Fraud Database, de Food Shield Database en RASFF. Dit datamodel bestaat uit de velden:

- Voedsel-productcategorie, bijv. dierlijke producten

- Voedsel-productgroep, bijv. vlees

- Fraude issue

- Analysemethode, bijv. microscopie

- Analysetechniek, bijv. optische microscopie

De motivatie voor het indelen op twee niveaus (productcategorie en productgroep) is dat er op deze manier snel zichtbaar kan worden gemaakt binnen welke categorieën en productgroepen het vaakst fraude voorkomt.

Wat betreft 'fraude issue' kan worden aangegeven wat er met het product is gebeurd, door te kiezen uit de volgende opties:

- Cultivar/soort (in geval van vlees betekent dit bijv. het (gedeeltelijk) verwisselen van het soort vlees in het product)

- Productsamenstelling

- Productkwaliteit

- Geografische herkomst

- Productiesysteem

- Illegale import

- Certificeringsissues

- Anders

In paragraaf 4.4 stellen we een uitgebreider model voor op basis van gesprekken met de retailers die mogelijk deel willen nemen aan een Nederlands Food Integrity Net.

\subsection{Food Industry Intelligence Network (FIIN)}

Het Food Industry Intelligence Network (FIIN) bestaat uit producenten, retail en food services in het Verenigd Koninkrijk. Er zijn tussen de 20 en 30 bedrijven lid van het netwerk. De betreffende leden leveren gegevens aan die vervolgens worden geanonimiseerd en verwerkt. Dit resulteert in een rapport dat teruggekoppeld wordt naar de leden. Hierin staan resultaten in de vorm van trendanalyses op basis van de uitkomsten van labtesten.

De aan FIIN deelnemende bedrijven leveren elk kwartaal de resultaten aan van alle laboratoriumtests die door het respectievelijke bedrijf zijn uitgevoerd voor authenticatiedoeleinden. Er wordt van de bedrijven verwacht dat ze alle testresultaten aanleveren, zowel de positieve als de negatieve resultaten. Voor FIIN is het belangrijk of productwaarden wel of niet binnen de aangegeven grenzen 
vallen. Wanneer dit niet zo is, maakt het niet uit of dit door een opzettelijke fout of toevallige oorzaak komt. Het doel van het verzamelen van data is het identificeren van patronen. Op een geaggregeerd niveau, zo redeneert men, zullen patronen vooral zichtbaar worden wanneer er geen sprake is van toevalligheden. Omdat het doel slechts het identificeren van trends is (en niet handhaving), worden onregelmatigheden niet verder onderzocht. De geïdentificeerde trends worden besproken door een technische stuurgroep, waar vertegenwoordigers van de verschillende partijen uit het netwerk in deelnemen. Vervolgens worden de trends, in de vorm van een geanonimiseerd en geconsolideerd rapport met de overige leden van het netwerk gedeeld. De deelnemende bedrijven kunnen zelf bepalen of ze op basis van de gerapporteerde trends actie ondernemen, zoals het interne testbeleid aanpassen om meer op een bepaalde productgroep te focussen.

De deelnemers van het netwerk leveren de testresultaten aan in spreadsheets. Hierbij wordt gebruik gemaakt van voorgedefinieerde dropdown-menu's. Voor het veld 'producttype' wordt een standaardclassificatie uit een Food Standards Agency database gebruikt. In het eerste dropdownmenu kan men bijvoorbeeld voor 'gevogelte' kiezen, waarna in het volgende menu gespecificeerd kan worden dat het om 'kip' gaat en vervolgens dat het om 'gekookte kip' gaat. Ook is er de mogelijkheid om aan te geven of het om een individueel of samengesteld product gaat (bijvoorbeeld 'gekookte kipstukjes' versus 'gekookte kip in soep'). Een ander dataveld legt vast wat het doel van de test was. Dit kan bijvoorbeeld het bepalen van het vochtgehalte, diersoort of herkomstland zijn, of bepalen of een product biologisch is. Hier kan in een volgend dropdown-menu het testtype worden ingevoerd. Wanneer in het eerste menu 'diersoort' wordt gekozen, kan vervolgens bijvoorbeeld 'PCR' of 'sequencing van het hele genoom' worden gekozen. Ook is er ruimte voor commentaar als vrije tekst, al wordt geprobeerd om dit tot een minimum te beperken. De datum waarop een monster genomen wordt of een test wordt uitgevoerd wordt niet ingevoerd. Deze informatie is niet nodig omdat telkens na drie maanden alle data van de afgelopen periode geconsolideerd verwerkt wordt. 


\section{$4 \quad$ Eisen en datamodel}

Het is belangrijk dat de verschillende deelnemers binnen het beoogde netwerk hetzelfde verstaan onder het begrip voedselfraude. In dit hoofdstuk presenteren we enkele definities uit de literatuur. Daarna omschrijven we de eisen die we stellen aan een integriteitsnetwerk op basis van onze gesprekken met de retailers als mogelijke netwerkdeelnemers. Het hoofdstuk eindigt met een voorstel voor de datavelden voor een toekomstig netwerk.

\subsection{Definities van voedselfraude}

Definities van fraude zijn belangrijk als basis voor het rapporteren van voedselfraude-incidenten. Het moet duidelijk zijn voor degene die informatie invoert in, of ophaalt uit een toekomstige Dutch Food Integrity Net-interface, wat we onder voedselfraude verstaan, omdat er anders onnodige verwarring kan ontstaan.

In de literatuur vinden we verschillende definities van voedselfraude, enkele van de meest gebruikte zijn:

- Voedselfraude is een verzamelnaam die wordt gebruikt om de opzettelijke en geplande vervanging, toevoeging, manipulatie of onjuiste voorstelling van voedsel, voedselingrediënten of voedselverpakkingen aan te duiden; of valse of misleidende verklaringen over een product voor economisch gewin. ${ }^{2}$

- Voedselfraude is alle acties die worden ondernomen door bedrijven of individuen die andere bedrijven en/of individuen misleiden in termen van verkeerde voorstelling van voedsel, voedselingrediënten of voedselverpakkingen die financieel gewin opleveren. ${ }^{3}$

- Voedselfraude is het bedriegen van consumenten gebruikmakend van voedselproducten, ingrediënten en verpakkingen voor economisch gewin en omvat vervanging, nietgoedgekeurde verbeteringen, merkfouten, namaak, gestolen goederen en andere. ${ }^{4}$

Uit deze definities wordt duidelijk dat fraude verwijst naar een handeling en de bedoelingen erachter, en niet naar het resultaat ervan. Resultaten van fraude zijn soms niet te onderscheiden van problemen met voedselveiligheid, kwaliteit of integriteit veroorzaakt door (het ontbreken van) andere acties.

Het is ook belangrijk om te beseffen dat fraude vaak resulteert in een inconsistentie tussen het fysieke product (of ingrediënt) zelf en de weergave ervan (specificatie op het etiket of anderszins). In het geval van dergelijke inconsistenties is het niet altijd duidelijk of de hoofdoorzaak in het product of de weergave ervan lag.

De vertegenwoordigers van de retailers zijn het erover eens dat er een eenduidige definitie van voedselfraude moet zijn, op basis waarvan bepaald wordt welke gevallen in de database worden opgenomen. Ze stellen zich ook voor dat een Nederlandse voedselfraude-database op den duur kan worden samengevoegd met databases van andere Europese landen en merken op dat het in dit geval nuttig is nu al een eensluidende definitie te hanteren.

De gangbare definities van voedselfraude sluiten 'opzet' in; er worden moedwillig stappen in het productieproces verkeerd uitgevoerd. In de praktijk is het vaak echter niet duidelijk of iets opzettelijk (bijvoorbeeld uit winstbejag) verkeerd is gegaan of dat dit om een andere reden (zoals slordigheid, onkunde, etc.) is gebeurd. Volgens de retailers gaan er veel vaker dingen per ongeluk verkeerd dan dat er sprake is van fraude. Om er zeker van te zijn dat in ieder geval een groot deel van de fraudeincidenten in de database wordt opgenomen, kan het nuttig zijn om te spreken over 'mogelijke voedselfraude' in plaats van 'voedselfraude'. 


\subsection{Randvoorwaarden en eisen aan de database}

Uit onze gesprekken met de vertegenwoordigers van de retailers kwamen verschillende ontwerpkeuzen aan de orde die gemaakt moeten worden bij het ontwikkelen van een database. Men noemde de definitie van fraude, wie er inzicht krijgt in de data en wie er aan het netwerk deelneemt, hoe data aangeleverd wordt, hoe de database eruitziet, de mate van anonimiteit en wat voor output de deelnemende partijen verkrijgen en wie hier inzicht in krijgt.

Een duidelijke wens van de vertegenwoordigers van de retailers is dat er veel partijen mee zullen moeten doen. Er wordt verwacht dat de database pas echt nuttig zal zijn als de dekkingsgraad voldoende is. Hoe meer partijen er meedoen, hoe meer fraudemeldingen er worden aangeleverd en hoe beter trends in fraude geïdentificeerd kunnen worden. Wanneer er bovendien partijen uit de hele keten meedoen (en niet alleen retailers), geeft dit inzicht in voedselfraude die op andere plekken in die keten plaatsvindt. Ook voorkomt dit het beeld dat voedselfraude alleen een zaak van de retailers zou zijn.

Op basis van ons onderzoek kunnen we ieder geval de volgende randvoorwaarden voor een integriteitsnetwerk onderkennen:

- Vertrouwelijkheid: Dit houdt onder andere in dat gevoelige data verborgen blijft. Dit kan bijvoorbeeld door gevoelige data niet tezamen op één plaats op te slaan. Ook kan men verschillende niveaus van toegang definiëren voor verschillende typen gebruikers. Daarnaast is het mogelijk om data te anonimiseren, abstraheren of te aggregeren.

- Risico van 'vals positieve' rapportages: Voorkomen moet worden dat er (te veel) onterechte meldingen in het systeem opgeslagen worden. Dit kan onder andere gerealiseerd worden door te werken met een bepaalde vorm van 'user identity', anoniem voor andere gebruikers maar bekend voor de systeembeheerder. Dit staat echter weer opgespannen voet met de eis van anonimiteit.

Anonimiteit van de voedselproducent en de mogelijke fraudeur wordt belangrijk geacht, omdat het juridisch moeilijk is om naam en toenaam te noemen - hiervoor is zekerheid over de fraude nodig, die er normaal gesproken niet is. Wanneer de voedselproducent en de mogelijke fraudeur wel bekend is, maar de melder van het mogelijke fraudegeval anoniem blijft, bestaat er het gevaar dat iemand een concurrent in diskrediet kan brengen door valse meldingen te doen. Om deze reden worden anonimiteit van melder, producent en fraudeur gevraagd. Dit betekent ook dat herleidbaarheid van een fraudegeval naar een specifieke producent, fraudeur of melder voorkomen moet worden. Van zulke herleidbaarheid zou bijvoorbeeld sprake zijn wanneer het betroffen product te gedetailleerd wordt beschreven.

De vertegenwoordigers van de retailers vinden dat het aanleveren van data een voorwaarde moet zijn om data te mogen inzien ('voor wat hoort wat'). Om deze reden plaatst men vraagtekens bij een mogelijke deelname van de NVWA. Er wordt verwacht dat de NVWA, vanwege haar rol als toezichthouder, geen data zal aanleveren. Een ander genoemd nadeel van deelname van de NVWA is dat dit mogelijk andere partijen zal afschrikken.

Het netwerk kan als output een periodiek rapport met trends en geaggregeerde data (zoals bij FIIN) opleveren. Het kan ook toegang verlenen tot de database, zodat deelnemers gericht kunnen zoeken naar specifieke gegevens, zoals voedselproduct, locatie of fraude-issue. De vertegenwoordigers van de retailers die wij gesproken hebben geven aan dat ze graag zowel een periodiek rapport als zelf toegang tot de database zouden willen krijgen. 


\subsection{Database: data velden en het aanleveren van data}

Er zijn verschillende manieren om mogelijke voedselfraude te ontdekken. Dit kan bijvoorbeeld tijdens een laboratoriumanalyse plaatsvinden die erop gericht is de authenticiteit van een product te onderzoeken, of tijdens een audit bij een voedselproducent. Het FIIN-initiatief in de UK werkt alleen met laboratoriumresultaten. Hierbij wordt echter van deelnemers verwacht dat ze al hun resultaten, zowel positieve als negatieve, aanleveren. Deze informatie helpt bij het inschatten van de risico's per productgroep.

De geraadpleegde retailers stellen dat wanneer er slechts wordt gekeken naar mogelijke fraudegevallen die met laboratoriumtests aan het licht zijn gekomen, er te weinig data zullen zijn. Elke retailer heeft beschikking over een interne database, waarin eigen analyseresultaten worden opgeslagen. Automatische data-aanlevering door koppeling van de eigen database met de voedselfraude-database wordt niet gewenst. De vertegenwoordigers willen zelf kunnen bepalen wat ze aan de database melden. Ook wordt directe koppeling technisch moeilijk of onmogelijk geacht. Omdat men enerzijds zelf controle over de data die ze aanleveren wil houden en anderzijds verwachten dat het slechts bekijken van laboratoriumanalyses tot niet genoeg mogelijke fraudegevallen zal leiden, kan het Engelse model voor data-aanlevering niet zonder meer gekopieerd worden.

Data-elementen die we met de vertegenwoordigers van de retailers besproken hebben zijn:

- Producttype

- Fraudetype

- Soort vervalsingsmiddel (ingrediënt dat onterecht aan het product is toegevoegd)

- Detectiemethode

- Locatie van de fraude

- $\quad$ Land van herkomst van het product

- Productiedatum of periode

- Detectiedatum

De retailers merken op dat het nuttig zou zijn om ook de fysieke locatie van de producenten op te slaan, zodat gekeken kan worden of het fraude-incident directe implicaties voor de eigen producten heeft. Het opengeven van deze informatie binnen het netwerk wordt echter niet realistisch geacht, omdat het herleidbaar maken van incidenten naar producenten strijdig is met de wens tot anonimiteit.

Ten slotte stellen we dat op de lange termijn de data uit NL-FINE als input kunnen dienen voor de tool voor het voorspellen van voedselfraude zoals die is ontwikkeld bij Wageningen University \& Research ${ }^{5}$.

\subsection{Voorgesteld gegevensmodel}

Gebaseerd op de bestaande oplossingen, het in de literatuur voorgestelde uniform data model en de discussies met retailers, stellen we een datamodel voor voor het toekomstige Nederlandse Food Integrity Net. Hierbij gaan we uit van de volgende vier punten:

1. Het gaat alleen om bedrijven die onderling hun data delen.

2. Het idee is om meldingen van (veronderstelde) voedselfraude te registreren.

a. Onder (veronderstelde) voedselfraude wordt verstaan dat er (mogelijk) sprake is van systematische en substantiële verschillen tussen het product en de weergave ervan, bijvoorbeeld op het etiket.

b. De registratie beperkt zich tot feitelijke gegevens.

3. Het doel van de registratie is om de deelnemende bedrijven te voorzien van informatie, zodat zij kunnen inschatten of er een link is tussen een geregistreerde melding en hun eigen toeleveringsketen.

4. Opgeslagen data kunnen (in de toekomst) een basis zijn voor risicoinschattingen en early warning systems. 
Het voorgestelde datamodel is weergegeven in Tabel 1.

Tabel 1: Voorgesteld datamodel

\begin{tabular}{|c|c|}
\hline Dataveld & Toelichting \\
\hline Meldingsdatum & $\begin{array}{l}\text { De meldingsdatum geeft een indicatie van een } \\
\text { mogelijke link in de tijd met de eigen keten }\end{array}$ \\
\hline $\begin{array}{l}\text { Productgegevens (wettelijke naam, product ID, } \\
\text { batchnummer, productiedatum) }\end{array}$ & $\begin{array}{l}\text { Product en productiedatum geven een indicatie van } \\
\text { een mogelijke link qua product en in de tijd met de } \\
\text { eigen keten }\end{array}$ \\
\hline Productbeschrijving & $\begin{array}{l}\text { Nadere beschrijving van het product geeft een } \\
\text { mogelijk link aan met eigen producten }\end{array}$ \\
\hline \begin{tabular}{|cl} 
Type fraude \\
- & Cultivar/soort \\
- & Productsamenstelling \\
- & Productkwaliteit \\
- & Geografische herkomst \\
- & Productiesysteem \\
- & Illegale import \\
- & Certificeringsissues \\
- & Anders
\end{tabular} & $\begin{array}{l}\text { Geeft een indicatie van wat voor type fraude er } \\
\text { mogelijk gaande is }\end{array}$ \\
\hline 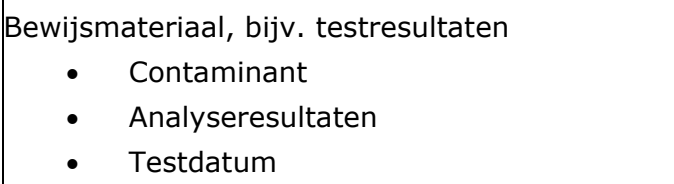 & $\begin{array}{l}\text { Geeft een indicatie van het bewijsmateriaal, en dus } \\
\text { hoe serieus deze melding moet worden genomen }\end{array}$ \\
\hline
\end{tabular}




\section{$5 \quad$ Conclusies en vervolg}

Er bestaat belangstelling bij het bedrijfsleven voor opzetten van NL-FINE, een digitaal platform voor het delen van informatie over incidenten met (mogelijke) voedselfraude. In eerste instantie zijn drie grote retailorganisaties gepeild. Zij zijn geïnteresseerd als het platform iets toevoegt aan bestaande informele onderlinge communicatie. Verder stelt men als voorwaarde dat er brede deelname vanuit de keten is, dat die deelname anoniem is en dat alleen bedrijven meedoen. CBL heeft al eerder belangstelling getoond en FNLI bespreekt het voorstel met haar deelnemers.

Het Britse initiatief FIIN kan dienen als voorbeeld voor NL-FINE. Zij stellen echter geen data ter beschikking, maar alleen trendanalyses. Verder neemt FIIN alleen fraude op basis van lab testresultaten op. Beide aannames zijn waarschijnlijk niet van toepassing bij NL-FINE.

In dit rapport hebben we een eenvoudig datamodel voor het netwerk voorgesteld. Voor het vervolg zouden in 2021 de volgende activiteiten uitgevoerd kunnen worden.

- $\quad$ Andere partijen in de keten polsen

- $\quad$ Een stuurgroep inrichten om de belangen van de verschillende partijen te vertegenwoordigen

- Gedetailleerd plan van eisen en ontwerp database opstellen

- $\quad$ Systeemontwikkeling en test

- Beperkte gebruikstest en evaluatie

De volgende stap is om een gedetailleerd projectvoorstel met concrete vervolgacties voor te leggen aan het Ministerie van LNV. 


\section{Literatuur}

1. Weesepoel, Y. J. A., van Ruth, S.M., Inventarisatie van voedselfraude: mondiaal kwetsbare productgroepen en ontwikkeling van analytische methoden in Europees onderzoek, 2015. https://edepot.wur.nl/360164

2. Spink, J., Moyer, D.C. (2011), Defining the Public Health Threat of Food Fraud. Journal of Food Science. 2011; 76: R157-R163. https://doi.org/10.1111/j.1750-3841.2011.02417.x

3. Elliot, C. Food Fraud 2018 Event, Opening Speech

4. GFSI Position on Mitigating the Public Health Risk of Food Fraud Report, 2014

5. Bouzembrak Y., Marvin H.J.P., Prediction of food fraud type using data from Rapid Alert System for Food and Feed (RASFF) and Bayesian network modelling. Food Control. 2016; 61:180-187187. https://doi.org/10.1016/j.foodcont.2015.09.026 



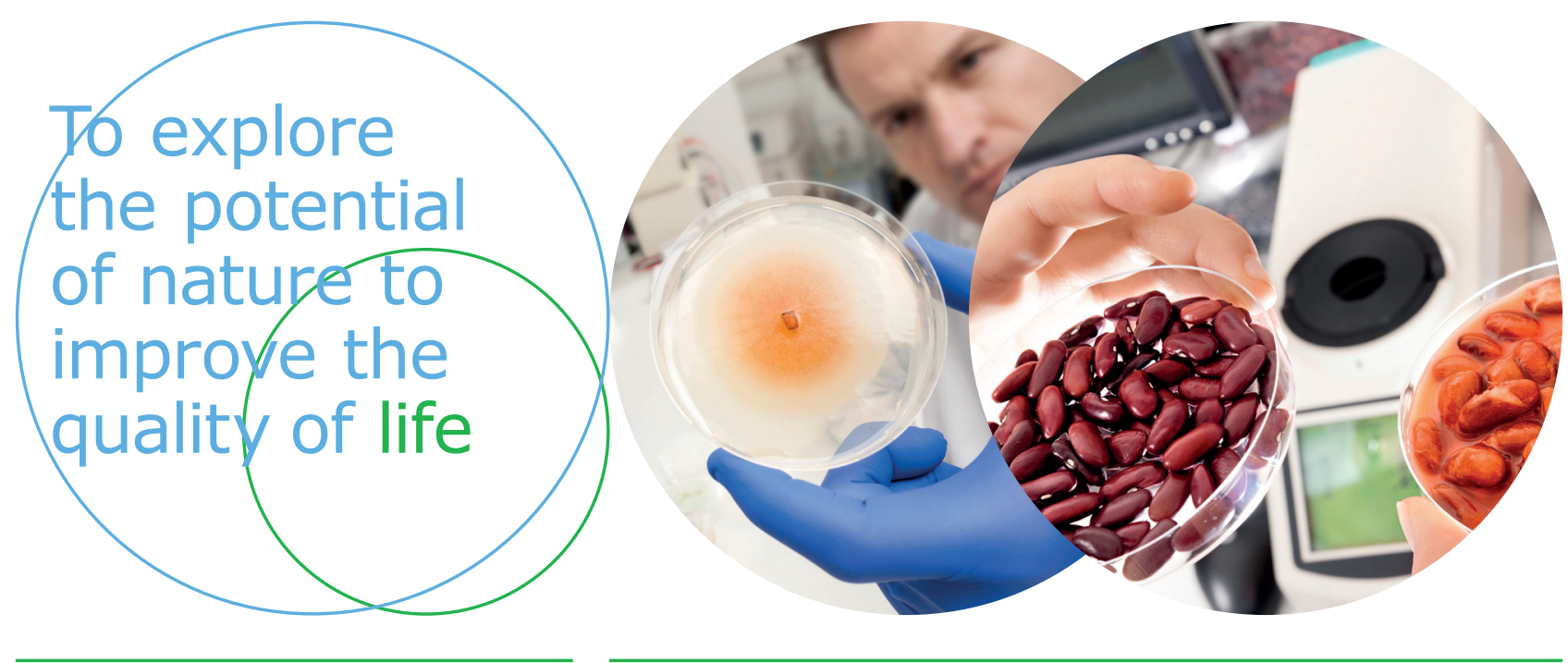

Wageningen Food \& Biobased Research Bornse Weilanden 9

6708 WG Wageningen

www.wur.nl/wfbr

info.wfbr@wur.nl

Rapport 2112

Vertrouwelijk
De missie van Wageningen University \& Research is 'To explore the potential of nature to improve the quality of life'. Binnen Wageningen University \& Research bundelen Wageningen University en gespecialiseerde onderzoeksinstituten van Stichting Wageningen Research hun krachten om bij te dragen aan de oplossing van belangrijke vragen in het domein van gezonde voeding en leefomgeving. Met ongeveer 30 vestigingen, 6.500 medewerkers (5.500 fte) en 12.500 studenten behoort Wageningen University \& Research wereldwijd tot de aansprekende kennisinstellingen binnen haar domein. De integrale benadering van de vraagstukken en de samenwerking tussen verschillende disciplines vormen het hart van de unieke Wageningen aanpak. 